\title{
SUBACUTE THYROIDITIS
}

\author{
By Selwyn TaYlor, M.Ch., F.R.C.S. \\ Surgeon, King's College Hospital, Belgrave Hospital for Children, and Hammersmith Hospital; \\ Lecturer in Surgery, Postgraduate Medical School of London
}

The term ' thyroiditis' implies inflammation of the thyroid gland, but by long usage it has come to be used for a number of conditions in which infection or trauma play apparently no part. Subacute thyroiditis is the title given to a condition which was first clearly described by de Quervain in 1904 and which has been rediscovered, or redescribed, on a number of occasions since then, with the result that it now has a multiplicity of different names: granulomatous thyroiditis, giantcell thyroiditis, pseudotuberculous thyroiditis, creeping thyroiditis, struma granulomatosa, acute non-infectious thyroiditis, acute non-suppurative thyroiditis and de Quervain's thyroiditis. For those who prefer eponymous nomenclature, the term ' de Quervain's thyroiditis' offers a satisfactory description of the disease. In recent years there have been some good reviews of the subject and the reader is referred to Crile (1948), Hazard (1955), Lindsay (1952 and 1954) and Taylor (1955).

The article which de Quervain published in 1904 described a condition which he called non-purulent thyroiditis and this distinctly separated from other thyroid conditions what we here describe as subacute thyroiditis. His article, which was beautifully illustrated with photomicrographs, gave a clear description of the condition which was only recognized, and even then under a variety of names, on some 60 occasions in the next 30 years. In 1936 Professor de Quervain, together with Dr. Giordanengo, of Turin, wrote a further account of the condition, adding eight fresh examples. In 1948 Crile again drew attention to the condition and emphasized that this was the same as pseudotuberculous thyroiditis; it is probably more to this surgeon than to anyone else that we owe the universal interest in this condition today.

\section{Incidence}

It would be a truism to say that subacute thyroiditis occurs most commonly where it is most commonly recognized, but, in fact, it is only where clinicians are constantly thinking about the condition that it is diagnosed. Again, rather as in bird-nesting, it is the discovery of the first example which leads to the finding of many more; once the condition has been properly recognized it seems to become much more common in that particular clinic. I had never seen an example before 1950, but saw six in the next three years and progressively more each year since then. The condition is much commoner in women than men in the ratio of about six to one. It has not yet been reported in a child and is commonest in the fourth and fifth decades, although $I$ have seen it in a student teacher of twenty-one. In our own series there was a history of a pre-existing goitre in 50 per cent. of the patients. The incidence, compared with that of Hashimoto's thyroiditis and Riedel's thyroiditis, varies widely in different clinics, but our own figures are most closely in agreement with those of Lindsay in San Francisco, who finds Hashimoto's disease about io times as common as de Quervain's and de Quervain's about to times as common as Riedel's.

\section{Clinical Picture}

The onset is typically acute, the patient com-plaining of a sore throat, malaise, fever and a tender or even exquisitely painful thyroid gland, the pain radiating up towards the ears. The patient often sweats profusely at night and complains of weakness and lassitude. However, few patients require or wish to be admitted to hospital and they may be able to carry on with their work, though feeling extremely weak while so doing.

The tenderness may start in one lobe of the gland, but almost invariably spreads to the other side until the whole of the thyroid is involved. The thyroid gland is then moderately enlarged and on palpation has a distinctive rubbery feel. It is firm as in Hashimoto's thyroiditis, but the edges are not so well defined, nor does the gland feel so mobile in the neck. This, of course, is in keeping with the finding of many adhesions of the capsule to the surrounding tissues which tether the gland to the strap muscles. With the passage of time one of two things happens to the gland: either it returns to a normal size and normal consistence or fibrosis is so intense that the gland feels hard. In the latter case the surface has the bosselated feel which is so typical of Hashimoto's disease, and this irregularity, combined with hardness and fibrosis, makes the differentiation from cancer a difficult one. 
The progress of the disease is almost always to spontaneous resolution and this usually occurs between three to six months after the onset. One patient under my care complained of symptoms for a little over a year, but this appears to be unusual.

\section{Differential Diagnosis}

The early stages of de Quervain's disease, with fever, sweating and a painful swollen neck, may well be mistaken for signs of thyroiditis due to acute bacterial inflammation. Whereas in acute thyroiditis the causative organism is almost always discovered, the white cell count is raised and there is a relative increase of polymorphonuclear leukocytes; none of these is found in subacute thyroiditis. One confusing point, however, is that both these conditions are often preceded by acute infection in the upper respiratory tract and especially a sore throat or tonsillitis.

The commonest condition which is mistaken for subacute thyroiditis is haemorrhage into a nodule of a simple nodular goitre. When there is a solitary nodule almost filling one lobe of the gland and there is haemorrhage into this, it is often very difficult to be certain of the right diagnosis. The patient has a painful swollen neck and the pain may radiate up to the ears, occasionally the temperature is elevated and certainly such patients almost always complain of malaise and fatigue. One important point of differentiation is that the erythrocyte sedimentation rate (E.S.R.) is almost invariably elevated in subacute thyroiditis. The other important differentiating test between the two conditions is that the radioactive iodine test for uptake in the gland is nil in the early stages of subacute thyroiditis, whereas there is always a fair uptake in simple nodular goitre.

The most serious condition which may be confused with subacute thyroiditis is carcinoma of the thyroid gland, especially the slow-growing papillary form seen in young adults. Crile and Fisher (1953) described two patients in whom a needle biopsy had been done to confirm the diagnosis of subacute thyroiditis. When the tissue was examined it was found to contain carcinoma and the patients were then treated by thyroidectomy. Finally, Hashimoto's thyroiditis may be mistaken for that of de Quervain. Occasionally a rather florid form of Hashimoto's thyroiditis is seen, especially in males, and this offers many of the features of the clinical picture and pathological findings of subacute thyroiditis. From the clinical point of view the Hashimoto patients progress inevitably towards myxoedema, which is not seen with the subacute cases, and, in addition, the pathologist sees the plump red Askanazy or Hurthle cells together with much lymphoid tissue in the excised gland.

\section{Laboratory Findings}

Just as the clinical findings are so much more important than the laboratory findings in Gravest disease, so in subacute thyroiditis too much reliance should not be placed on special investiga tions. However, they may provide valuable supe portive evidence where the diagnosis remains it doubt, but they also require considerable skit in their interpretation, since they change with the progress of the disease, which may extend fror three to 12 months.

The white cell count remains unaffected and the relative proportions of lymphocytes and polye morphonuclear leucocytes are unchanged. This is in contrast with the changes seen in bacteriat thyroiditis. The erythrocyte sedimentation rafe is raised and may be as high as $50 \mathrm{~mm}$. Westergre in the first weeks of the disease. No organisms or viruses have so far been isolated from the्ट thyroid tissue or blood of these patients, but thigo does not exclude their presence and, indeed, mantw workers have felt very strongly that a virus was responsible.

In the early weeks of the disease it is usual to find that the radioactive iodine uptake in the neck is zero and, since this is not seen in any othe thyroid condition, it is one of the strongest points in favour of the diagnosis. As the months go क्ष the radioactive iodine uptake returns and aftex a year it is usual for it to be once more nornato On the other hand, the level of protein-bound iodine in the serum may be high in the first week of the disease (Lindsay, 1954), but subsequentl is lower than normal and does not return to the usually accepted level of approximately $4 \mu \mathrm{g}$. pe $\overrightarrow{5}$ cent. until after a year or 18 months has elapsed.

A most useful ancillary method in coming to $\$$ diagnosis in this disease is the employment $\overrightarrow{\text { of }}$ needle biopsy. Many types of instrument have been used, but one of the simplest, which can be carried ready sterilized in an ordinary clinical bag is the Vim-Silverman split needle (Crile ant. Hazard, 195 I ; Taylor, I955). The patient is aske@ to lie on a couch and the neck is hyperextended by means of a pillow. The skin is prepared with at antiseptic and then with a hypodermic needle tiny weal is raised using 2 per cent. Lignocaine르. A tenotomy knife or spear-pointed scalpel is then used to nick the skin and the trocar and cannula of the Vim-Silverman needle is introduced, the thyroid being steadied with fingers placed behind the sternomastoid. As soon as the needle is felt to engage the surface of the gland, the trocar is removed and the split needle inserted in its place and pushed forward so that the blades enter the gland. The most important part of the manoeuvreo then follows, which consists of holding the splie part of the needle quite rigidly still and the 

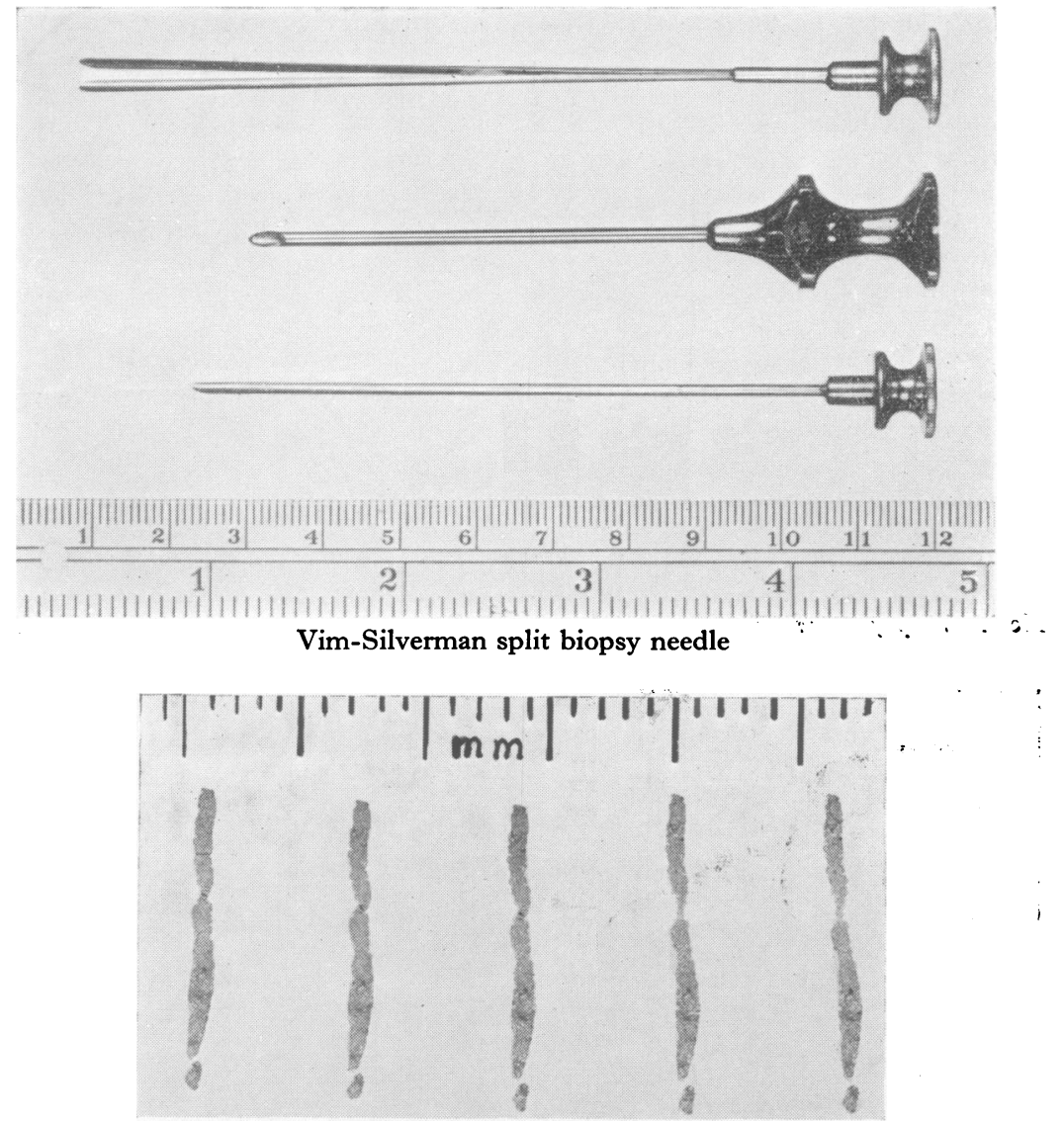

Actual specimen of needle biopsy after section

pushing forward the outer cannula over the blades so that they are brought together and grip a piece of thyroid tissue. The needle is then twisted and drawn out and should have between its blades a core of biopsied material. The illustrations show the individual components of the needle and also an actual specimen after it has been fixed and sectioned. After the needle has been withdrawn it is necessary to apply firm pressure for a few minutes to the neck and then apply a small collodion dressing over the skin wound. We have made a rule of asking the patient to remain lying down for at least a quarter of an hour after this form of biopsy and no serious complications have so far resulted. An excellent account of the technique has been given by Hamlin (1955, 1956). Heptinstall and Eastcott (1954) have described the removal of a portion of the isthmus in making the diagnosis of thyroiditis and this is a very suitable alternative technique.

\section{Pathology}

The gland in subacute thyroiditis is always en- larged and this enlargement may be superimposed upon a previous simple goitre. The consistence is firm and the colour paler than usual, there being no increase in vascularity. It is noticeable that the capsule is thicker and becomes adherent to the surrounding structures, though in no way comparable to the intense fibrosis seen in Riedel's thyroiditis. The gland resembles most of all that seen in Hashimoto's disease, but is not so rubbery, although the surface is similarly bosselated, and, on the whole, it feels tougher when cut with a knife.

The histological changes depend on the stage of the disease at which the tissue is examined; in the beginning there is a generous infiltration by lymphocytes and plasma cells which tend to be arranged in clumps. The follicles may appear largely normal, but in certain foci follicular cells will be seen to have swelled up and disrupted and the aggregations of their nuclei mimic giant cells, hence the name giant-cell thyroiditis. True giant cells may also appear and it is possible that they phagocytose the colloid from the destroyed fol- 


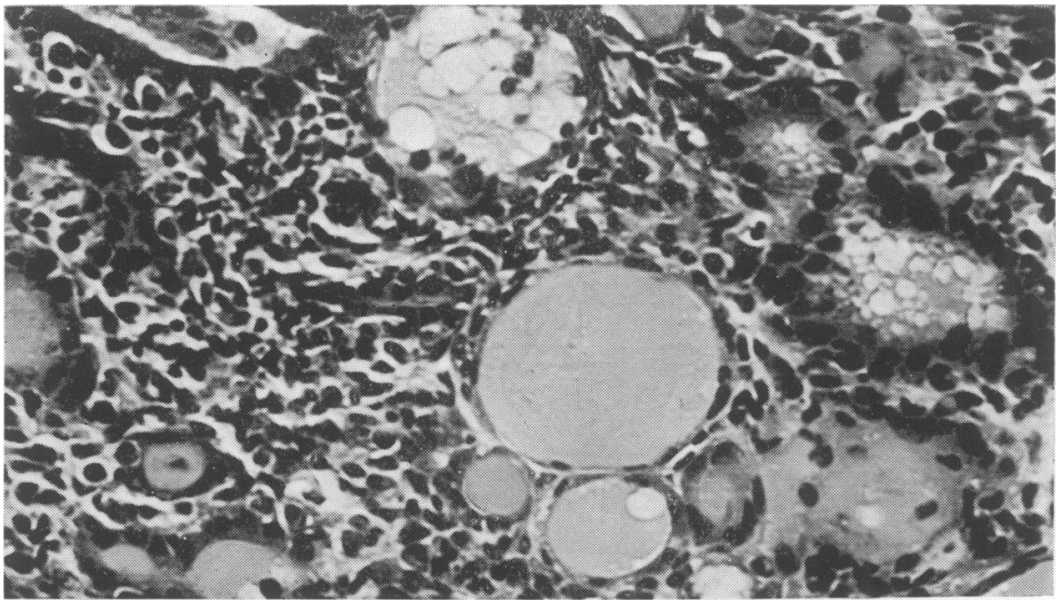

Needle biopsy showing disintegration of follicles and pseudo-giant-cells $(\times 350)$.

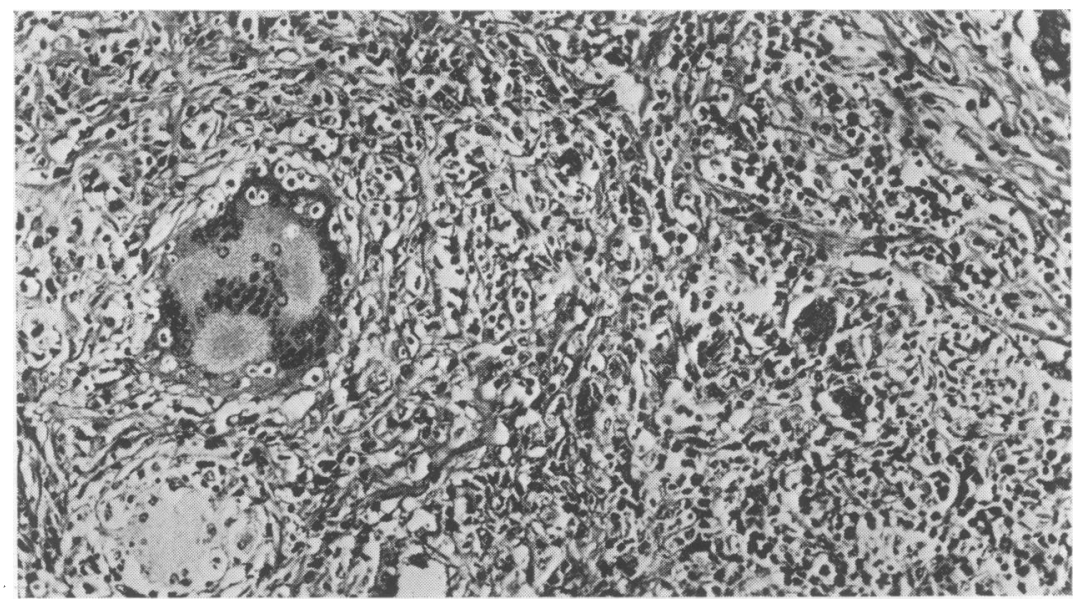

No normal follicles now remain. Note large foreign-body giant-cell.

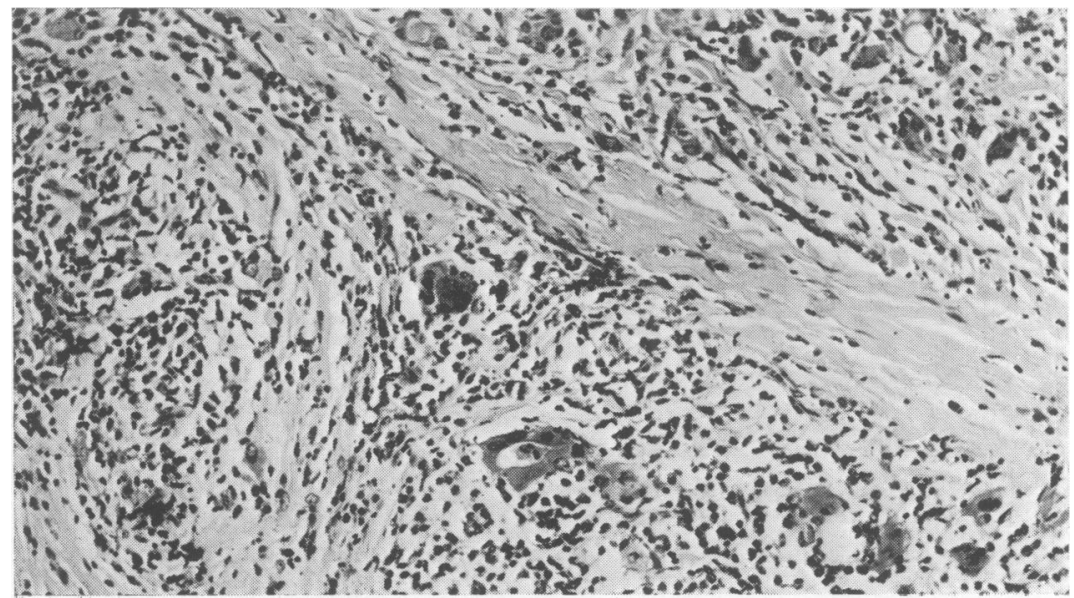

i Section showing increase in fibrous stroma. 
licles. With the passage of time the fibrous stroma becomes greatly increased and fibrosis is the most prominent feature of the histology. The changes are seen in the accompanying three photomicro'graphs, which illustrate typical areas from biopsy specimens obtained by a needle. Perhaps the most important point in differential diagnosis histologically is that of papillary carcinoma. Certainly macroscopically the two conditions may appear very similar when confined to focal areas and it is only by examination under the microscope that an appreciation of the difference is obtained. Most workers who have studied the histological changes in subacute thyroiditis have been impressed with the resemblance which it sometimes shows with Hashimoto's disease and with certain features of hyperthyroidism. Indeed, there are occasionally patients in whom the diagnosis remains in doubt both clinically and histologically and it should not be thought that an absolutely clear distinction can be made between different forms of thyroiditis. On the whole, most glands can be put into the category of Hashimoto's, Riedel's or de Quervain's thyroiditis, but this is not always so and only long observation of the patient gives the final answer.

\section{Aetiology}

There is no proven factor in the aetiology of this form of thyroiditis, but there is certainly no lack of speculation. Cultures of the material have always proved negative, but since the condition often follows infection in the upper respiratory tract a virus has been incriminated. Fraser and Harrison (1952) suggested such an aetiology, but Lindsay was unable to demonstrate the histological features, such as inclusion bodies, which it might be expected should be present. Certainly some of the histological changes might be considered, due to the fact that the colloid acts as a foreign body when the follicles disrupt, and some of the phagocytic changes seen would fit in with this. Fraser suggested that the virus affected the follicular cells much as thiouracil does in blocking hormone production, but it is interesting that giving thiouracil to such a patient usually relieves the condition and allows iodine uptake. Possibly this is due to the potentiation of thyrotrophic hormone which thiouracil is known to bring about. In support of this is the work of Robbins and Rawson, who demonstrated that patients with subacute thyroiditis were relieved of their symptoms and again showed a radioactive iodine uptake in the neck when injected with thyrotrophic (T.S.H.) hormone. My own view is that this condition results from a localized hypersensitivity to toxins, probably those from streptococci, as the condition so commonly follows a sore throat. Just as in HenochSchonlein's purpura, where there is a hyper- sensitivity to such circulating toxins. The response of the condition to cortisone is very suggestive of such a mechanism, but much further evidence will have to be obtained before a satisfactory working hypothesis is capable of being presented. Finally, Perloff (1956) has recently reported five cases of hyperthyroidism following proven attacks of subacute thyroiditis.

\section{Treatment}

Since subacute thyroiditis is a self-limiting disease any form of treatment may eventually be given claims which they do not really deserve and, in fact, a multitude of different therapies have been suggested. The first landmark was the announcement by King and Rosellini (1945) that thiouracil in ordinary doses caused cessation of pain and constitutional symptoms within a few days of being started by mouth. The possible mechanisms which have been put forward to explain this are that thiouracil potentiates the action of T.S.H. from the pituitary. As described above, Robbins and his colleagues (195 r) describe similar good results with injections of T.S.H. and certainly the uptake of radioactive iodine by the thyroid is reinstated by this technique. Crile originally advocated the use of radiotherapy for this condition, but most of us have given up its employment because, although a response can usually be obtained, it is desirable to avoid X-ray therapyos when other forms of treatment are equally effec-? tive. Recently a number of workers have described good results from the use of cortisone (Clark, Nelsen and Raymond, 1953; Titleman and Rosenburg, 1953; Lasser, 1953; and Kahn and his. colleagues, 1953). On the whole, this has been found the best form of therapy and seldom fails to produce a response in about a week's time. The drug has to be continued by mouth until the disease reaches a natural remission, and this can only be found by experiment. Small doses of cortisone are usually adequate after the first week and it is most desirable that the dosage be kept to the lowest level which gives an adequate clinical response. It may be added that carbimazole in 5-mg. doses three times a day produces an equally good result and may eventually be reduced to only $5 \mathrm{mg}$. a day, but it is not unusual to get some increase in the size of the gland and cortisone provides a more satisfactory form of treatment at the present time. It should also be added that no kind of antibiotic has been found to produce any response.

\section{Postscript}

Some interesting new work stems from an observation by Cooke and Wilder in 1954 that the serum colloidal gold curve in Hashimoto's disease is usually abnormal. They added to this the belief 
that liver changes usually accompanied the condition (Cooke and Luxton, 1955) and a larger confirmatory series appeared from the Cleveland Clinic (Skillern, 1956) last year. The raised $\gamma$ globulin levels, their delayed return to normal after thyroidectomy and the infiltration of the thyroid with lymphocytes, plasma cells and lymphoid tissue prompted Roitt et al. (1956) to look for an immune response. They have reported a precipitin reaction of serum with extract of human thyroid gland and they postulate that it parallels the destruction of the patient's own thyroid, and especially the colloid, by an auto-antibody.

It might well be expected that in subacute thyroiditis a similar positive flocculation test would be obtained and W. R. Trotter and D. Doniach inform me that they have obtained a positive reaction in the serum of two patients with this disease.

For those who are interested in recent advances in problems of immunology and thyroid disease there is an excellent leading article in the Lancet, May 25, 1957, Vol. I, p. I075, which reviews the whole subject up to the present time. This has now become one of the rapidly expanding frontiers of thyroid investigation.

\section{Acknowledgment}

We are indebted to the publishers of British
Surgical Progress 1955 for the blocks which apped in this article.

\section{BIBLIOGRAPHY}

CLARK, D. E., and NELSEN, T. S. (1953), four. Amer. med. Ass COOKE, 551 . T., and WILDER, E. (1954), Lancet, $i_{1} 984$. COOKE, R. T., and LUXTON, R. W. (1955), Ibid., 1, 968.

CRILE, G., Jr. (1948), Ann. Surg., 127, 640., Cancer, 6, 57. . 흘. CRILE, G., Jr., and HAZARD, J. B. (r951), $\}$. clin. Endock CRILE, G., Jr., and RUMSEY, E. W. (1950), f. Amer. med. As

DE QUUE, $45^{8}$. DE QUERVAIN, F., and GIORDANENGO, G. (1935), Ibid.. FRA ${ }^{4}{ }^{538}$.

HAMLIN, E., Jr., and VICKERY, A. L.'(1956), New Eng. Med., 214, 742.

HAZARD, J. B. (1955), Amer. F. clin. Path., 25, 399. HEPTINSTALL, R. H., and EASTCOTT, H. H. G. (195过

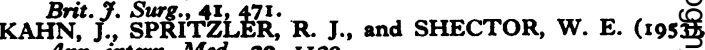
Ann. intern. Med., 39, II29, L. J. (1945), F. Amer. med. Ass. KING, B. T.

LASSER, R. P. (1953), Ibid., 152, 1133.

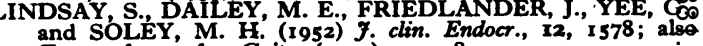
Trans. Amer. Ass. Goiter (1052), pp. 384-411.

LINDSAY, S., and DAILEY, M. E. (1954), Surg. Gynec. Obstent, PERĹ, 197. W. H. (1956), \%. clin. Endocr., 16, 542.

PERLOFF', J., RALL, J. E., TRUNNELI, J. B., and RAWSO R.W.(1951) Ibid. 11, 1106.

ROITT, I. M., DONIACH, D., CAMPBELL, P. N., and HUDSÓN, R. V. (1956) Lancet, il, 820 .

SKILLERN, P. G., CRILE, G., MCCULLAGH, P., HAZARF J. B., LEWIS, L. A., and BR̈OWN, H. (1956), $\mathscr{\mathcal { F }}$. clin. Endocr. 16, 33. S. (1955), ' Brit. Surg. Progress,' pp. 148-160, Lorgofo

\section{RUTHIN CASTLE, NORTH WALES}

A Clinic for the diagnosis and treatment of Internal Diseases (except Mental or Infectious Diseases). The Clinic is provided with a staff of doctors, technicians and nurses.

The surroundings are beautiful. The climate is mild. There is central heating throughout. The annual rainfall is 30.5 inches, that is, less than the average for England.

The Fees are inclusive and vary according to the room occupied.

For particulars apply to THE SECRETARY, Ruthin Castle, North Wales.

Telegrams: Canke, Ruchin.

Telepheme: Ruchin 66

Bibliography continued from page 326-Fames Crooks, M.B., M.R.C.P.(Lond. and Ed.), F.R.F.P.S.G.

FRANKLIN, A. L., LERNER, S. R. and CHAIKOFF, I. L.,

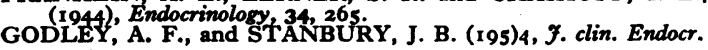
I4t? 70.

GOODWIN, J. F., STEINBERG, H., and WILSON, A. (1954), GRIESBACH, W', E., KENNEDY, T. H., and PURVES, H. D. (1941), Brit. F. exp. Path., 22, 249.

HIMSWORTH, H. P. (1948), Brit. med. F., 2, 61

IVERSEN, K. (1951), $\mathcal{F}$. clin. Endocr., II, 298 .

KENNEDY, T. H. (1942), Nature (Lond.), 150, 233.

KRISS, J. P., CARNES, W. H., and GROSS, R. T. (1955),

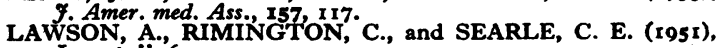

MARINE, D., BAUMMANN, E. J., SPENCE, A. W., and CIPRA, A. (1932), Proc. Soc. exp. Biol. (N.Y.), 29, 772.

MOORE F. D. (1946), \&. Amer. med. Ass., 130, 315.

MORGANS, M. E., and TROTTER, W. R. (r954), Lancet, i, 749.
MCCULLAGH, E. P., HUMPHREY, D. C., MCGARVEY, C. 甹 and SUNDGREN, V. (1951), $\mathcal{F}$. Amer. med. Ass., 147, 106. MCCULLAGH, E. P., and SURRIDGE, W. T. (1948), $\mathcal{F}$. cling MACGREG̈OR, A. G., and MILLER, H. (1953), Lancet, i, 88I MACGREGOR, A. G., and SOMNER, A. R. (I954), Ibid., ii, 93 PEMBERTON, J. J., HAINES, S. F., and KEATING, F. R (1949), Ұ. clin. Endocr., 9, 1232.

PLUMMER, H. S. (1923), Ұ. Amer. med. Ass., 80, 1955

SOLEY, M. H. (1942), Arch. intern. Med., 70, 206. SOLEY, M. H. (1942), Arch. intern. Med., 70, 206.
STANLEY, M. M., and ASTWOOD, E. B. (1947), Endocrinology

STANLEY, M. M., and ASTWOOD, E. B. (1949), Ibid.. 44,58 WLLYMS, R. H., TOWERY, B. 2 , WOLFF, I., CHAIKOFF, I. L., GOLDBERG, R.' C., ant MEIER, J. R. (1949), Endocrinology, 45, 504.
WYNGAARDEN, J. B., WRIGHT, B. M., and WAYS, P. (ros 2 क्ष
Ibid., 50, 537. Ibid., 50, 537 . 